PAWEl CZAPLińsKi

Akademia Pomorska, Słupsk

\title{
Funkcjonowanie przemysłu przetwórstwa rybnego w Polsce w okresie kryzysu gospodarczego
}

Procesy transformacji systemu społeczno-gospodarczego w Polsce, związane z przechodzeniem od centralnego systemu zarządzania gospodarką do systemu gospodarki rynkowej, wpływają w zasadniczym stopniu na gruntowne zmiany funkcjonowania poszczególnych sektorów gospodarki narodowej, przedsiębiorstw przemysłowych i usługowych oraz instytucji otoczenia biznesu. Wyrazem tego jest przebudowa struktur przemysłowych, która dokonuje się w wyniku zmian funkcjonowania przedsiębiorstw przemysłowych, traktowanych jako podstawowe elementy przestrzennych form koncentracji przemysłu. W centralnym systemie sterowania przedsiębiorstwa przemysłowe funkcjonowały $\mathrm{w}$ warunkach gospodarki planowej, co polegało na wykonywaniu zadań wyznaczonych przez plany jednostek nadrzędnych i wpływało na ograniczenie samodzielności przedsiębiorstw w zakresie zasobów majątkowych, wielkości i asortymentu produkcji, kierunków zbytu, zaopatrzenia w surowce i materiały, struktur organizacyjnych, zatrudnienia, a także kierunków rozwoju. W stosunkowo niewielkim stopniu sprzyjało to modernizacji procesów produkcji, podnoszeniu jakości asortymentu produkcji i wdrażaniu innowacji (Rachwał 2006).

We wprowadzanym od dwudziestu lat w Polsce systemie gospodarki rynkowej w otoczeniu przedsiębiorstw pojawiły się nowe uwarunkowania ich funkcjonowania (w tym proces integracji europejskiej), a mechanizmy konkurencji zaczęły mieć istotne znaczenie w zmianie kierunku działalności przedsiębiorstw oraz ich selekcji. Proces dostosowania się przedsiębiorstw przemysłowych do ciągle nowych warunków gospodarowania wymaga od nich przeprowadzenia radykalnych zmian w funkcjonowaniu, prowadzących do podniesienia ich konkurencyjności. Zmiany te warunkują uczestnictwo krajowych przedsiębiorstw przemysłowych w europejskich procesach gospodarczych i integrację polskiego przemysłu z przemysłem nie tylko europejskim, ale również światowym, zwłaszcza w drodze powiązań organizacyjnych, kapitałowych, technologicznych, a także wchodzenie w ukształtowane sieci rynkowe ponadnarodowych korporacji (Rachwał 2006).

W ostatnich latach najważniejszym zadaniem, przed jakim stanęły polskie przedsiębiorstwa, była obrona przed negatywnymi skutkami kryzysu gospodarczego. Należy jednak podkreślić, że wpływ kryzysu na funkcjonowanie przedsiębiorstw w Polsce jest raczej umiarkowany, zdecydowana bowiem większość podmiotów nie została zmuszona do przyjmowania radykalnych strategii. Nie pojawił się również w dużej skali (w porównaniu do pozostałych państw UE) silny spadek rentowności, masowe zwolnienia czy też zaległości płatnicze i brak dostępu do kredytów (NOBE 2010; Szewczyk 2010). 
Podejmowane działania w przedsiębiorstwach koncentrowały się zatem na wykorzystywaniu szans rozwojowych wynikających z nieprzewidywalnej sytuacji. Według niektórych autorów został w ten sposób sformułowany nowy paradygmat zwany „chaotyką” (Kotler, Caslione 2009; Orłowski, Pasternak i in. 2010).

W świetle wszystkich powyższych przesłanek za istotne przyjęto identyfikację procesów zachodzących w przemyśle przetwórstwa rybnego w Polsce, a w konsekwencji próba odpowiedzi na pytanie, czy i jak kryzys finansowy i związany z nim kryzys gospodarczy wpłynął na funkcjonowanie przedsiębiorstw przetwórstwa rybnego.

\section{CHARAKTERYSTYKA PRZEMYSŁU PRZETWÓRSTWA RYBNEGO}

Przetwórstwo rybne to obecnie jedna z najbardziej dynamicznie rozwijających się grup działalności przemysłu spożywczego w Polsce. Po okresie wyraźnego zastoju w pierwszych latach wprowadzania gospodarki rynkowej nastąpiły tu głębokie i radykalne zmiany restrukturyzacyjne, które pozwoliły na szybki wzrost konkurencyjności, a w konsekwencji wzrost wielkości produkcji sprzedanej ogółem. W ostatnim dziesięcioleciu produkcja sprzedana przemysłu przetwórstwa ryb wzrosła ponadtrzykrotnie (Czapliński 1999; Koszarek 2005; Szostak, Rakowski, Budny 2010).

Przemysł przetwórstwa rybnego należy do jednej z najmniejszych grup przemysłu spożywczego ${ }^{1}$. Wynika to nie tylko z wielkości zatrudnienia, które na koniec 2009 r. wyniosło 18,4 tys. osób, ale również z udziału ryb w imporcie i eksporcie rolno-spożywczym (odpowiednio $9,0 \%$ i 7,0\%), udziału przetwórstwa ryb w wartości produkcji sprzedanej przetwórstwa rolno-spożywczego (3,5\%), ale nade wszystko z udziału przetwórstwa rybnego w PKB, które w 2009 r. wyniosło zaledwie 0,04\% (Seremak-Bulge 2009). Jednocześnie w tym samym roku przetwórstwo rybne generowało produkcję na poziomie około 4,5 mld PLN, co w przeliczeniu na jednego pracującego dawało kwotę około 244,6 tys. PLN. Kwota ta wskazuje jednoznacznie, że przetwórstwo rybne charakteryzuje się bardzo wysokim wskaźnikiem produktywności i efektywności, a w opinii wielu znacznie przewyższa wszystkie pozostałe sektory przetwórstwa rolno-spożywczego, łącznie z mięsnym i mleczarskim (Bykowski 2010).

Wielkość produkcji polskiego przemysłu przetwórstwa rybnego (w grupie przedsiębiorstw średnich i dużych) w ostatnim dziesięcioleciu (2000-2009) jest dość stabilna i waha się od około 260 do 320 tys. ton rocznie. Natomiast duże różnice w wielkości produkcji ogółem wynikają z bardzo różnych zachowań małych przetwórni, w których zwłaszcza po polskiej akcesji do struktur europejskich zaszły istotne zmiany organizacyjne i technologiczne (ryc. 1).

Zasadniczym zmianom ulega również wartość produkcji, jest to skutek istotnego postępu w przetwórstwie i wprowadzaniu coraz większej grupy produktów o wysokim stopniu uszlachetnienia i tym samym dużej wartości dodanej. W 2009 r. wartość dodana osiąnęła poziom 195,7\% wartości z roku 2003.

\footnotetext{
${ }^{1}$ Przemysł przetwórstwa rybnego rozumiany jest jako działalność związana z przetwarzaniem i konserwowaniem ryb, skorupiaków i mięczaków. Według PKD jest to grupa 10.2 należąca do działu 10 . o nazwie produkcja artykułów spożywczych oraz do sekcji C, określonej jako przetwórstwo przemysłowe.
} 


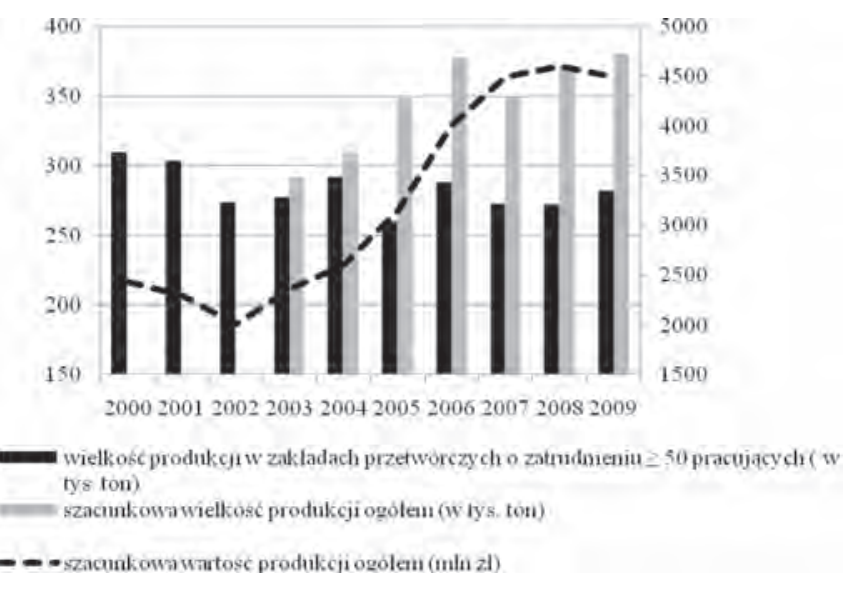

Ryc. 1. Wielkość i wartość przetwórstwa rybnego w Polsce w latach 2000-2009

Źródło: opracowanie własne na podstawie danych Morskiego Instytutu Rybackiego w Gdyni publikowanych w raportach „Morska Gospodarka Rybna” za lata 2003-2009

W latach 2004-2009 w strukturze produkcji największy udział miały ryby przetworzone i zakonserwowane, których udział w produkcji ogółem mimo wyraźnych wahań nie był zagrożony. Z roku na rok wzrastał udział ryb wędzonych i pozostałych produktów, często wysoko przetworzonych, takich jak pasty, pasztety itp. Spadła natomiast istotnie wielkość produkcji ryby świeżej nisko lub wcale nieprzetworzonej oraz ryby solonej, na co mogło mieć wpływ propagowanie diety zawierającej mało soli (ryc. 2).

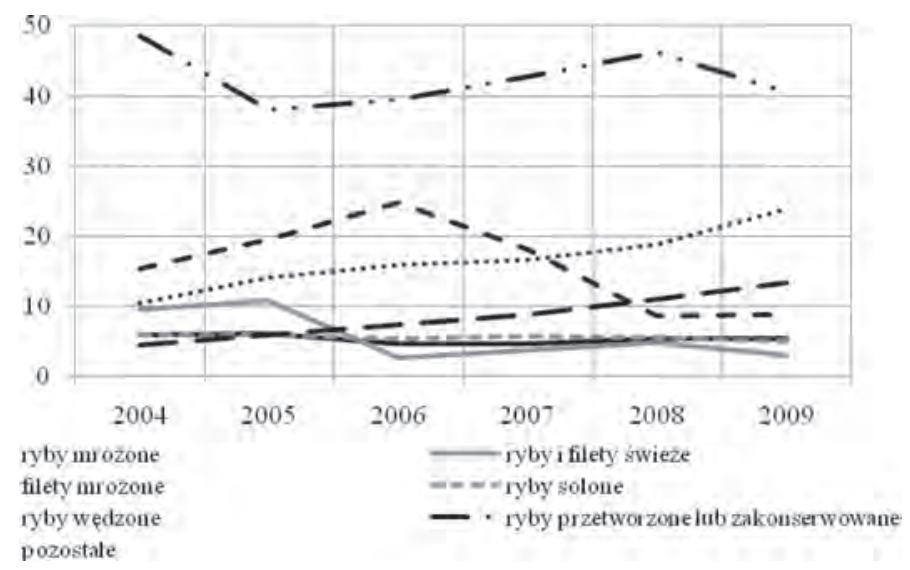

Ryc. 2. Struktura asortymentowa przetwórstwa rybnego w Polsce w latach 2004-2009

Źródło: opracowanie własne na podstawie danych Morskiego Instytutu Rybackiego w Gdyni publikowanych w raportach „Morska Gospodarka Rybna” za lata 2003-2009 
Według m.in. K. Hryszko (2010) i P.J. Bykowskiego (2010), krajowe przetwórstwo ryb w latach 2005-2009 było w bezpiecznej sytuacji finansowej, o czym świadczy prawidłowy dopływ środków finansowych, wysoki poziom rentowności, stały poziom współczynnika płynności finansowej oraz systematyczne obniżanie zobowiązań handlowych i skarbowych. Ponadto należy dodać, że dobra kondycja finansowa przedsiębiorstw w badanym okresie dotyczyła zdecydowanej większości jednostek produkcyjnych, a ich odsetek z roku na rok wzrastał, głównie na skutek bardzo wysokiej rentowności w sprzedaży (tab. 1.).

Tab. 1. Sytuacja finansowa przetwórstwa ryb*

\begin{tabular}{|l|c|c|c|c|c|}
\hline Wyszczególnienie & 2005 & 2006 & 2007 & 2008 & $2009^{* *}$ \\
\hline Koszty finansowe (\% przychodów) & 1,09 & 1,11 & 1,31 & 3,98 & 7,07 \\
\hline Rentowność brutto (\%) & 1,99 & 3,17 & 3,62 & 2,31 & 4,78 \\
\hline Rentowność netto (\%) & 1,52 & 2,50 & 2,70 & 1,78 & 3,80 \\
\hline $\begin{array}{l}\text { Płynność bieżąca } \\
\text { (aktywa bieżace / zobowiqzania bieżqce) }\end{array}$ & 1,21 & 1,24 & 1,28 & 1,18 & 1,45 \\
\hline Inwestycje (w mln zł) & 146 & 160 & 256 & 269 & 71,8 \\
\hline Udział firm rentownych w ogólnej liczbie firm (\%) & 75,0 & 81,7 & 82,2 & 82,3 & 76,4 \\
\hline $\begin{array}{l}\text { Udział firm rentownych w sprzedaży } \\
\text { w ogólnej liczbie firm (\%) }\end{array}$ & 59,9 & 74,0 & 91,1 & 81,8 & 71,1 \\
\hline
\end{tabular}

* - w przedsiębiorstwach zatrudniających 10 i więcej osób

** - I półrocze $2009 \mathrm{r}$.

Źródło: Seremak-Bulge 2009, I ranking przetwórstwa rybnego, Instytutu Ekonomiki Rolnictwa i Gospodarki Żywnościowej

Po wejściu Polski do Unii Europejskiej można mówić o szczególnym ożywieniu inwestycyjnym w krajowym sektorze przetwórstwa rybnego, dzięki bardzo aktywnie prowadzonej polityce pozyskiwania kredytów, a następnie funduszy pomocowych (w tym funduszu SAPARD). Obecnie przetwórstwo rybne właściwie absorbuje środki unijne, dzięki Programowi Operacyjnemu RYBY ${ }^{2}$, którego główną zaletą jest sprzyjanie prorynkowemu nastawieniu polskiego przetwórstwa rybnego. Wielkość przewidywanego dofinansowania polskiego rybołówstwa i przetwórstwa rybnego w latach 2007-2010 wyniesie ok. 1 mld EURO. Warto podkreślić, że tak dużego wsparcia polskie przetwórstwo rybne jeszcze nigdy nie miało w swej historii.

Na koniec października 2010 r. wykorzystanie alokacji PO RYBY wyniosło 44,27\% ${ }^{3}$. $\mathrm{Z}$ czego największe dotychczasowe zaangażowanie środków pomocowych przypadało na dostosowanie floty rybackiej do nowych uwarunkowań rynkowych w ramach wspólnego, europejskiego rynku oraz na pobudzenie funkcjonowania akwakultury, rybactwa śródlądowego, przetwórstwa i obrotu produktami. Pozyskane środki finansowe były i są nadal w dużej mierze wykorzystywane głównie na inwestycje techniczne i technologiczne, co w opinii wielu ekspertów przyczyniło się do tego, że obecnie Polska ma jedne z najnowocześ-

${ }^{2}$ Pełna nazwa Programu Operacyjnego RYBY to „Zrównoważony rozwój sektora rybołówstwa i nadbrzeżnych obszarów rybackich 2007-2013".

${ }^{3}$ Informacja na temat wdrażania Programu Operacyjnego ,Zrównoważony rozwój sektora rybołówstwa i nadbrzeżnych obszarów rybackich 2007-2013” w październiku 2010 r., Wydział Kontroli, Monitorowania i Raportowania Wykorzystania Funduszy Pomocowych, Ministerstwo Rolnictwa i Rozwoju Wsi, Warszawa 2010. 
niejszych w Europie zakładów przetwórstwa rybnego. Duże zaawansowanie technologiczne, wysoka sprawność techniczna i wynikająca z tego wysoka wydajność pracy w połączeniu z bardzo dobrą jakością produktów i ciagle relatywnie niskimi kosztami pracy przesądzaja o wysokiej konkurencyjności polskiego przetwórstwa rybnego w skali całej UE.

W świetle powyższych przesłanek nie zaskakuje fakt, że eksport ryb i przetworów rybnych z Polski do krajów UE w ostatnim dziesięcioleciu systematycznie rósł. W latach 2008 2009 osiagnął on poziom ponad $800 \mathrm{mln}$ EURO, co pozwala na kreowanie optymistycznych perspektyw dla nowoczesnego polskiego przemysłu rybnego. Zwłaszcza że w 2009 r. odnotowano po raz pierwszy od czasu polskiej akcesji do struktur europejskich nieznaczne (około 5 mln EURO) dodatnie saldo bilansu handlowego (ryc. 3).

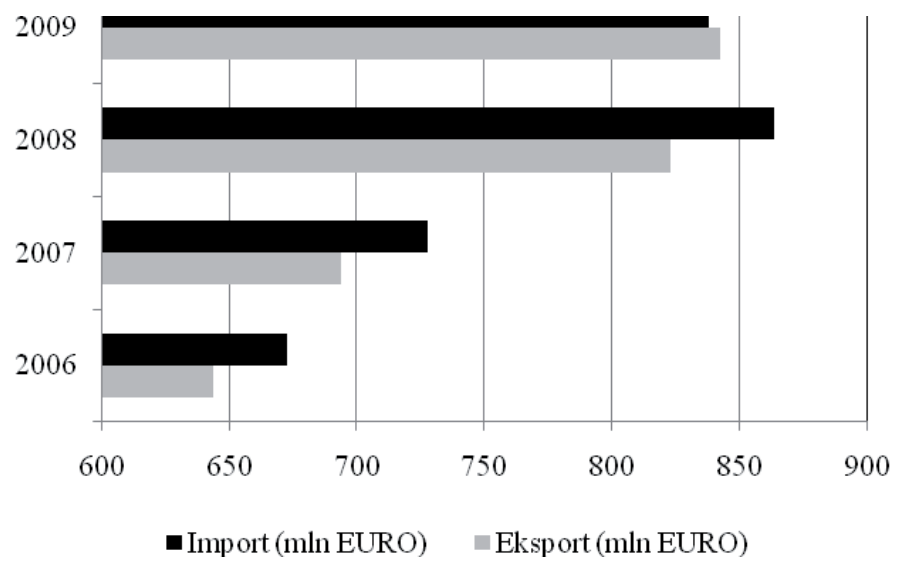

Ryc. 3. Obroty handlu zagranicznego rybami i przetworami rybnymi w Polsce w latach 2006-2009 w mln EURO

Źródło: Rynek Ryb. Stan i perspektywy, nr 13, Wyd. IERiGŻ-PIB, Warszawa

LOKALIZACJA PRZEDSIĘBIORSTW PRZEMYSŁU PRZETWÓRSTWA RYBNEGO W POLSCE

Według danych Głównego Inspektoratu Weterynarii z końca 2009 r. przetwórstwem ryb w Polsce zajmowało się 459 zakładów, z których 248 posiadało uprawnienia eksportowe, a 211 zakładów było uprawnionych do sprzedaży bezpośredniej tylko na rynek krajowy (Szostak, Rakowski, Budny 2010).

Rozmieszczenie terytorialne przedsiębiorstw przetwórstwa rybnego według województw jest bardzo nierównomierne. Ponad połowa zakładów uprawnionych do handlu produktami rybnymi na obszarze UE zlokalizowana jest w dwóch województwach nadmorskich, tj. pomorskim i zachodniopomorskim (razem 58,5\%). Wydaje się więc, że dostęp do surowca, zwłaszcza świeżego, duża tradycja wytwórczości oraz zgromadzony potencjał produkcyjny i ludzki nadal odgrywają znaczącą rolę w lokalizacji tego rodzaju działalności produkcyjnej. Warto jednak zauważyć, że przy podejmowaniu decyzji lokalizacyjnych związanych z omawianą działalnością produkcyjną rośnie znaczenie takich czynników lokalizacji, jak dostępność komunikacyjna (zwłaszcza czasowa) i bliskość rynku zbytu, szczególnie w odniesieniu do dużych aglomeracji miejskich, takich jak warszawska, górnośląska czy poznańska. Nie 
bez znaczenia pozostają także koszty pracy. Należy bowiem pamiętać, że znaczna część procesów obróbki ryb nadal opiera się na pracy wykonywanej ręcznie (ryc. 4).

A

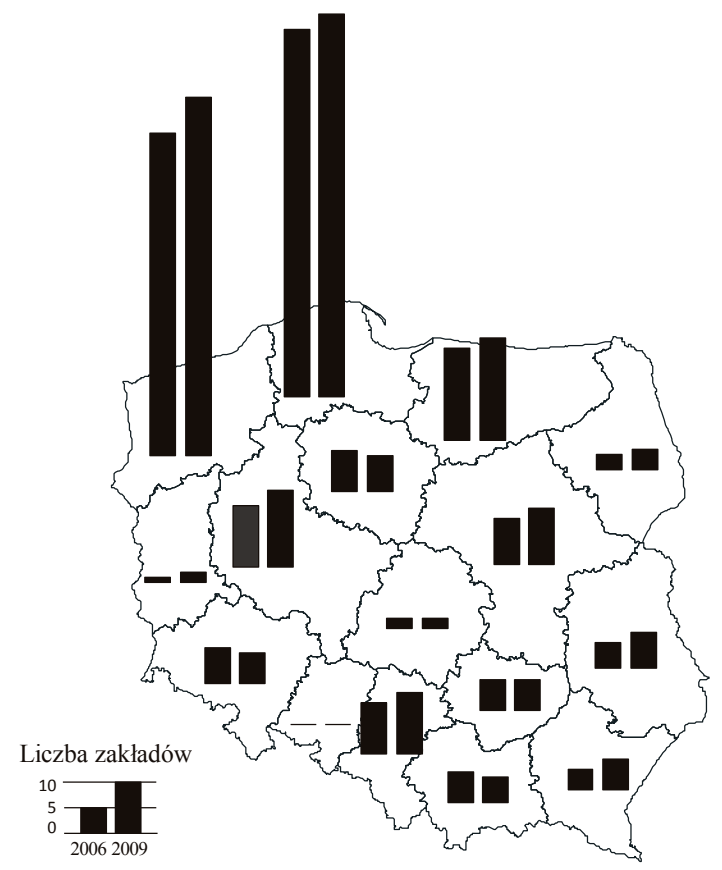

$\mathrm{B}$

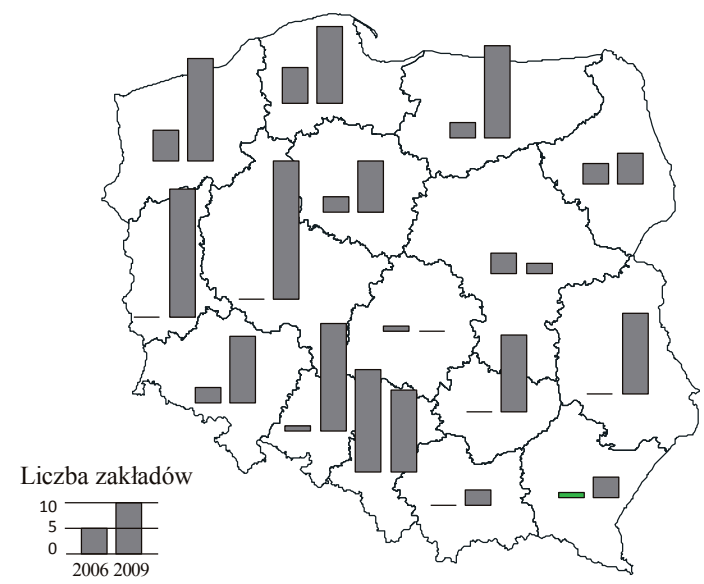

Ryc. 4. Zmiany struktury przestrzennej przemysłu przetwórstwa rybnego w Polsce w latach 2006-2009

A - zakłady przetwórcze uprawnione do sprzedaży bezpośredniej na rynek krajowy i rynek UE

B - zakłady przetwórcze uprawnione do sprzedaży bezpośredniej tylko na rynek krajowy

Źródło: opracowanie własne na podstawie danych Morskiego Instytutu Rybackiego w Gdyni zawartych w raportach „Morska Gospodarka Rybna” za lata 2003-2009 
Rozmieszczenie terytorialne zakładów przetwórczych uprawnionych do sprzedaży bezpośredniej tylko na rynek krajowy ma nieco inny rozkład przestrzenny. W województwach nadmorskich funkcjonuje niespełna $20 \%$ tego typu jednostek produkcyjnych, natomiast największa ich koncentracja występuje w województwach wielkopolskim i lubuskim, których łączny udział w ogóle zakładów jest bliski 25\%. Należy także zwrócić uwagę na znaczącą koncentrację zakładów w województwie warmińsko-mazurskim. Przyczyny wyraźnej koncentracji przedsiębiorstw w wyżej wymienionych województwach, podobnie jak w przypadku grupy zakładów uprawnionych do sprzedaży swoich produktów na rynki Unii Europejskiej, związane są z bazą surowcową. Baza ta odnosi się zasadniczo do akwakultur słodkowodnych, a te występują zwykle w strefie pojeziernej. W przypadku województwa śląskiego i opolskiego relatywnie duża koncentracja zakładów przetwórstwa rybnego wynika z korzystnego położenia komunikacyjnego, ale przede wszystkim z bliskości i dostępności do rynku zbytu, jakim jest m.in. aglomeracja katowicka. Ponadto za interesujący należy przyjąć fakt znacznego rozwoju przedsiębiorstw tej grupy, jaki nastąpił po 2006 r. Jego determinantą było uruchomienie programu operacyjnego „Zrównoważony rozwój sektora rybołówstwa i nadbrzeżnych obszarów rybackich 2007-2013”, a w szczególności drugiej osi priorytetowej związanej z inwestycjami w akwakultury i rybactwo śródlądowe.

Polskie przetwórnie - podobnie jak i w innych krajach UE - to przede wszystkim niewielkie, często rodzinne firmy o zatrudnieniu nieprzekraczającym 9 pracujących i chociaż na przestrzeni ostatnich kilku lat ich liczba uległa zmniejszeniu, to jednak nadal dominują one w strukturze wielkościowej zakładów przetwórczych. Jedną z przyczyn takiego stanu rzeczy jest obserwowany proces konsolidacji produkcji przetwórstwa rybnego, który nie sprzyja zwiększaniu zatrudnienia w poszczególnych spółkach zależnych. Drugą z przyczyn jest duża bariera podażowa, która ogranicza rozwój. Mimo to rośnie liczba przedsiębiorstw w grupie 50-249 pracujących, co wynika z sukcesów wiodących firm przetwórczych i ich rozwoju. Liczba zakładów, których załoga przekracza 250 osób, wynosi niecałe 3\% ogólnej liczby przedsiębiorstw tej branży (ryc. 5).

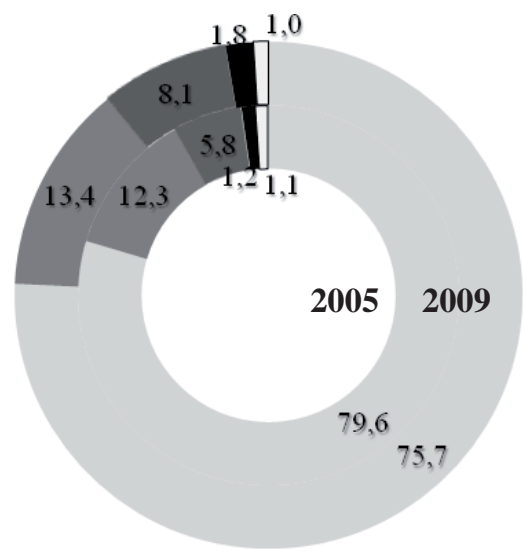

\section{9 i mniej $\square$ 10-49 $\square$ 50-249 $\square 250-499 \quad \square 500$ i więcej}

Ryc. 5. Struktura wielkościowa zakładów przemysłu przetwórstwa rybnego w Polsce

Źródło: opracowanie własne na podstawie Rocznika Statystycznego Gospodarki Morskiej, 2009, WUS, Szczecin; Seremak-Bulge 2009 


\section{Stymulanty i Destymulanty Rozwoju PRZetwórstwa Rybnego w Polsce}

Jak już wcześniej wspomniano, krajowy przemysł przetwórstwa rybnego znajduje się obecnie w dobrej kondycji finansowej, handlowej i technologicznej, a silnie odczuwany w innych branżach kryzys gospodarczy występuje w dużo mniejszej skali. Dzieje się tak dlatego, że istnieje szereg dodatkowych czynników rynkowych, które łagodzą skutki kryzysu w przetwórstwie rybnym. Jednym z takich czynników jest wielkość konsumpcji ryb. Zgodnie z kryteriami przyjętymi przez FAO (Organizację Narodów Zjednoczonych do Spraw Wyżywienia i Rolnictwa) do obliczania konsumpcji ryb w 2009 r. ${ }^{4}$, Polska znalazła się wśród państw o najniższej konsumpcji w UE. Przy średniej unijnej około $26 \mathrm{~kg}$ na osobę, wielkość ta dla Polski wyniosła 13,2 kg/os. Można zatem wysunąć tezę, że znacznie wyższy od krajowego popyt zagraniczny na ryby i ich przetwory jest siłą napędową polskiego przetwórstwa rybnego. Warto jednak dodać, że konsumpcja w Polsce w ostatnich latach wzrosła o około 1,5 kg/os. Ten relatywnie duży wzrost konsumpcji należy tłumaczyć tym, że w latach 2007-2009 zarysował się wyraźny trend wolniejszego wzrostu cen ryb w porównaniu do innych artykułów spożywczych, przyczyniły się również do tego „epidemie” grypy i innych chorób, które wzmogły zainteresowanie rybami jako swoistej alternatywy żywnościowej (Seremak-Bulge 2010).

Według P.J. Bykowskiego (2010), wśród innych ważniejszych czynników, które wpłynęły w ostatnim dwudziestoleciu na szczególnie intensywny rozwój przetwórstwa rybnego jako segmentu rynku żywnościowego, należy wymienić szybko zachodzące zmiany demograficzne. Rośnie bowiem liczba gospodarstw domowych jedno- i dwuosobowych, które wykazują duży popyt na żywność wysoce przetworzoną, w tym tzw. wygodną, co wynika z faktu odchodzenia od klasycznego modelu rodzinnego, a tym samym spożywania wspólnych posiłków. Ponadto zakupy żywności wygodnej (w przypadku branży rybnej są to np. paluszki i steki z różnych gatunków ryb, paluszki z karbów, pierścienie z kalmarów itp.) wynikają z dużej mobilności ludności i poznawaniu regionalnych potraw z całego świata. Być może to właśnie jest przyczyną dużej popularności w Polsce barów sushi.

Kolejnym czynnikiem determinującym sukces polskiego przetwórstwa ryb na rynku zjednoczonej Europy jest paradoksalnie rosnący deficyt surowca zgłaszany przez wiele krajów bloku. Już w 2006 r. jego poziom oceniano na 50\% (Zatrudnienie w sektorze rybolówstwa 2006). Podejmowane przez polskie przetwórnie działania polegają zasadniczo na niwelowaniu deficytu poprzez stałe dostawy nie tyle surowca co już wysoko przetworzonego produktu. Jak wskazuje A. Bronikowski (2009), przy poszukiwaniu coraz trudniej dostępnego surowca warto zwrócić uwagę na słabo wykorzystane rodzime gatunki ryb morskich, ale również znaczny potencjał rozwojowy produkcji ryb słodkowodnych.

Obecnie w polskim przetwórstwie rybnym dominują takie gatunki ryb, jak śledzie, szproty, łososie i dorsze.

Krajowe połowy śledzi bałtyckich w 2009 r. wzrosły w stosunku do roku poprzedniego o 30\% i wyniosły około 22 tys. ton, wielkość ta nie jest jednak w stanie zaspokoić zapotrzebowania krajowego przetwórstwa na ten gatunek ryb (Kuzebski 2010). Rosnąca podaż spowodowała, że już w połowie 2009 r., zaistniała konieczność wcześniejszego zamknięcia połowów5 Niedobory rekompensuje więc rosnący import szacowany na około 93 tys. ton rocznie, głównie

${ }^{4}$ Jako podstawę przyjmuje się wagę całych ryb po złowieniu. Źródło: www.fao.org/fishery/statistics.

${ }^{5} 10$ sierpnia 2009 ukazało się rozporządzenie Komisji WE, informujące o wyczerpaniu z dniem 8 czerwca polskiego limitu śledzi w obszarze 22-24 i zakazie dalszych połowów. 
z państw skandynawskich. Należy przy tym zauważyć, że śledź z racji m.in. niejednorodności jakościowej stanowi obecnie surowiec jedynie do wytwarzania niektórych konserw i marynat, a także stanowi potencjalne źródło surowca paszowego (Grygiel i in. 2009).

Głównym problemem połowów szprota bałtyckiego jest permanentne od wielu lat niewykorzystywanie przypadających na Polskę kwot połowowych. Tylko w latach 2005-2008 uśredniony stopień wykorzystania kwot połowowych wyniósł 45,1\%. W 2009 r. polskie statki złowiły 83 tys. ton szprotów, co daje w stosunku do 2008 r. aż 50\% wzrost połowów i $70 \%$ wykorzystanie polskiej kwoty.

Znaczny wzrost połowów nie byłby możliwy bez znaczącej pomocy szwedzkich armatorów, na których statki trafiło ponad 20 tys. ton szprotów. Większość tych ryb wyładowano w portach duńskich z przeznaczeniem na cele paszowe (Szostak 2009; Kuzebski, Szostak, Rakowski, Budny 2010). Niewykorzystywanie kwot połowowych wynika podobnie jak w przypadku śledzia z niejednorodności i niskiej jakości surowca, a ponadto z dużych uszkodzeń mechanicznych spowodowanych niewłaściwym postępowaniem ze złowionymi rybami na jednostkach połowowych, złymi metodami przechowywania chłodniczego, a także manipulacjami transportowo-przeładunkowymi w relacji statek rybacki - port - przetwórnia lądowa (Pawlikowski 2010). Ponadto szprot odznacza się stosunkowo niską atrakcyjnością na rynku detalicznym, co wynika z wspomnianych wcześniej zmian kulinarnych gustów. Od strony podażowej na uwagę zasługuje fakt, iż obróbka i pakowanie szprota wymaga dużego stopnia pracochłonności, m.in. ze względu na ręczne układanie konserw, tymczasem średnia cena rynkowa jest raczej niska. W świetle powyższego należy przypuszczać, że w następnych latach będzie wzrastał udział połowów tego gatunku na cele paszowe.

Za interesujący uznać można przypadek ryb łososiowatych. Jak wynika z opublikowanych danych, złowiono zaledwie 49 ton tych ryb lub 9,8 tys. sztuk, czyli zaledwie 50\% z liczącego 19,5 tys. sztuk limitu. Tymczasem zgłaszany popyt produkcyjny był kilkakrotnie wyższy. Rozwiązaniem stał się import. Wg szacunków w 2009 r. sprowadzono do kraju, głównie z Norwegii, blisko 75 tys. ton tej ryby. Trzeba podkreślić, że około 2/3 tej ilości została wyeksportowana w postaci wysoko przetworzonych produktów do krajów UE. Rósł także popyt konsumpcyjny na ryby łososiowate. Konsumpcja łososi w Polsce wzrosła z $0,16 \mathrm{~kg} / \mathrm{os}$. w $2001 \mathrm{r}$. do $0,56 \mathrm{~kg} / \mathrm{os}$ w 2009 r.

Rok 2009 był szczególnym rokiem również dla rybołówstwa dorszowego. W wyniku wprowadzonego nowego systemu podziału kwot połowowych liczba statków, które otrzymały zezwolenie na połowy tych ryb, zmniejszyła się do $1 / 3$ stanu z 2008 r. Pozostałe 2/3 w zamian za rekompensaty finansowe musiało zrezygnować połowów dorszy. Jednak nawet tak znaczne ograniczenie liczby statków dorszowych nie wpłynęło na wielkość osiąganych połowów, które wyniosły 11 tys. ton, czyli o 10\% więcej niż w 2008 r. (Kuzebski 2010).

Poza wymienionymi uwarunkowaniami połowowymi nie brak i innych zagrożeń dla działalności polskiego rybołówstwa i przetwórstwa ryb. Według P.J. Bykowskiego (2010), często pomijane i niedoceniane $\mathrm{w}$ wielu opracowaniach jest słabe dostosowanie procesu produkcyjnego do aktualnych wymagań ochrony środowiska, zgodnych z normami Unii Europejskiej.

Na podstawie analizy sytuacji połowowej podstawowych gatunków ryb wykorzystywanych w polskim przetwórstwie rybnym określić można wiele przyczyn zmian ilościowych łowionych ryb. Na uwagę zasługuje jednak fakt, iż mimo tego że część z nich ma charakter ekonomiczny, to nie są bezpośrednio związane ze skutkami kryzysu gospodarczego, a raczej ze znacznie dłuższymi czasowo trendami. 
Na podstawie wszystkich dotychczasowych rozważań można przyjać, że stosunkowo silna odporność krajowego przetwórstwa rybnego na skutki kryzysu gospodarczego wynika z wielu czynników zewnętrznych, które to znacząco wzmocniły mocne strony sektora, do których niewątpliwie należy wysoka jakość wysoko przetworzonych produktów wynikająca z dobrego jakościowo surowca (często importowanego), dobrze zorganizowanej i przygotowanej do pracy siły roboczej oraz nowoczesnego parku maszynowego (tab. 2).

Tab. 2. Analiza SWOT dla przemysłu przetwórstwa rybnego w Polsce, stan na 31.12.2009 r

\begin{tabular}{|l|l|}
\hline Mocne strony & Slabe strony \\
\hline Podniesienie jakości produktów & Niska konsumpcja ryb w Polsce \\
Duży udział produktów wysoko przetworzonych & Brak zorganizowanego systemu marketingu \\
Modernizacja zakładów przetwórczych & Duże rozdrobnienie przetwórstwa rybnego \\
Wysoki udział eksportu w sprzedaży & Sezonowość dostępu do surowca bałtyckiego \\
Tania siła robocza & Brak zorganizowanej sieci pierwszej sprze- \\
Wykształcona kadra technologiczna & daży \\
\hline Szanse & Zagrożenia \\
\hline Zmiana nawyków żywieniowych konsumentów & Duża konkurencja w UE \\
Wzrost zamożności społeczeństwa & Wysokie koszty standardów europejskich \\
Zorganizowany system marketingu & Malejące kwoty połowowe \\
Innowacyjność technologiczna & \\
Grupy producenckie & \\
Lańcuchy produkcyjne & \\
Rozwój akwakultury & \\
Powolny wzrost cen ryb & \\
\hline
\end{tabular}

Źródło: opracowanie własne z uwzględnieniem pracy M. Koszarek (2005)

Ponadto wydaje się, że niska konsumpcja ryb w Polsce jest rekompensowana poprzez wysoki eksport produkcji, głównie na rynki europejskie, a malejące kwoty połowowe oraz stopień ich wykorzystania poprzez import surowca, czasem z odległych łowisk. Konkurencyjność polskich przetwórni opiera się głównie na procesach konsolidacji, które mają zniwelować duże rozdrobienie przedsiębiorstw oraz brak dobrze zorganizowanych sieci handlowych i dystrybucyjnych, a jednocześnie uwypuklić dużą elastyczność i zdolność do szybkiej adaptacji rynkowej.

\section{PROCESY KONSOLIDACJI KRAJOWEGO PRZETWÓRSTWA RYBNEGO}

Współczesne zasady funkcjonowania rynku spożywczego, w tym przetwórstwa rybnego, skłaniają do refleksji, że konsolidacja w sferze produkcji, handlu i dystrybucji jest zabiegiem niezbędnym, ponieważ spowolnienie gospodarcze z jednej strony stanowi impuls do wzmacniania pozycji na rynku poprzez przejęcia lub połączenia, z drugiej zaś wymusza likwidację bądź całkowitą restrukturyzację przedsiębiorstw biernych, tzn. takich, które nie są zaangażowane w przejęcia lub też same nie stanowią takiego celu. O sukcesie przedsiębiorstwa stanowi zatem jego zdolność do wyróżnienia się na rynku i skłonienia nabywców 
do wybierania właśnie tych, a nie innych produktów (Brzózka, Stęniak 2010). Podkreśla się, że można to osiągnąć albo dzięki konkurencyjnej cenie, możliwej do osiągnięcia dzięki wykorzystaniu efektów skali, albo w wyniku zajęcia wysoce rentownej niszy, w której nie skala działalności się liczy, a raczej wysoka jakość i precyzyjna odpowiedź na specyficzne potrzeby konsumenta (Lipszyc 2010). Wydaje się, że obie te ścieżki są realizowane w krajowym przetwórstwie rybnym, ponieważ z jednej strony tworzące się od kilku lat krajowe grupy producenckie wykorzystują efekt skali, a z drugiej następuje proces przejmowania i rozbudowy przez polskie przedsiębiorstwa rynku przetwórstwa łososi w skali europejskiej. Należy podkreślić, że niezależnie od przyjętej ścieżki sukcesu rynkowego, o podniesieniu konkurencyjności przedsiębiorstw przetwórstwa rybnego decydują obecnie procesy konsolidacyjne, które będą nadal kontynuowane.

$\mathrm{Na}$ podstawie przeprowadzonych badań dotyczących wybranych przedsiębiorstw krajowego przetwórstwa rybnego można wyróżnić różne typy działań konsolidacyjnych. Jednym $\mathrm{z}$ nich jest konsolidacja produkcyjna, czego przykładem jest grupa GRAAL S.A. z Wejherowa (ryc. 6).

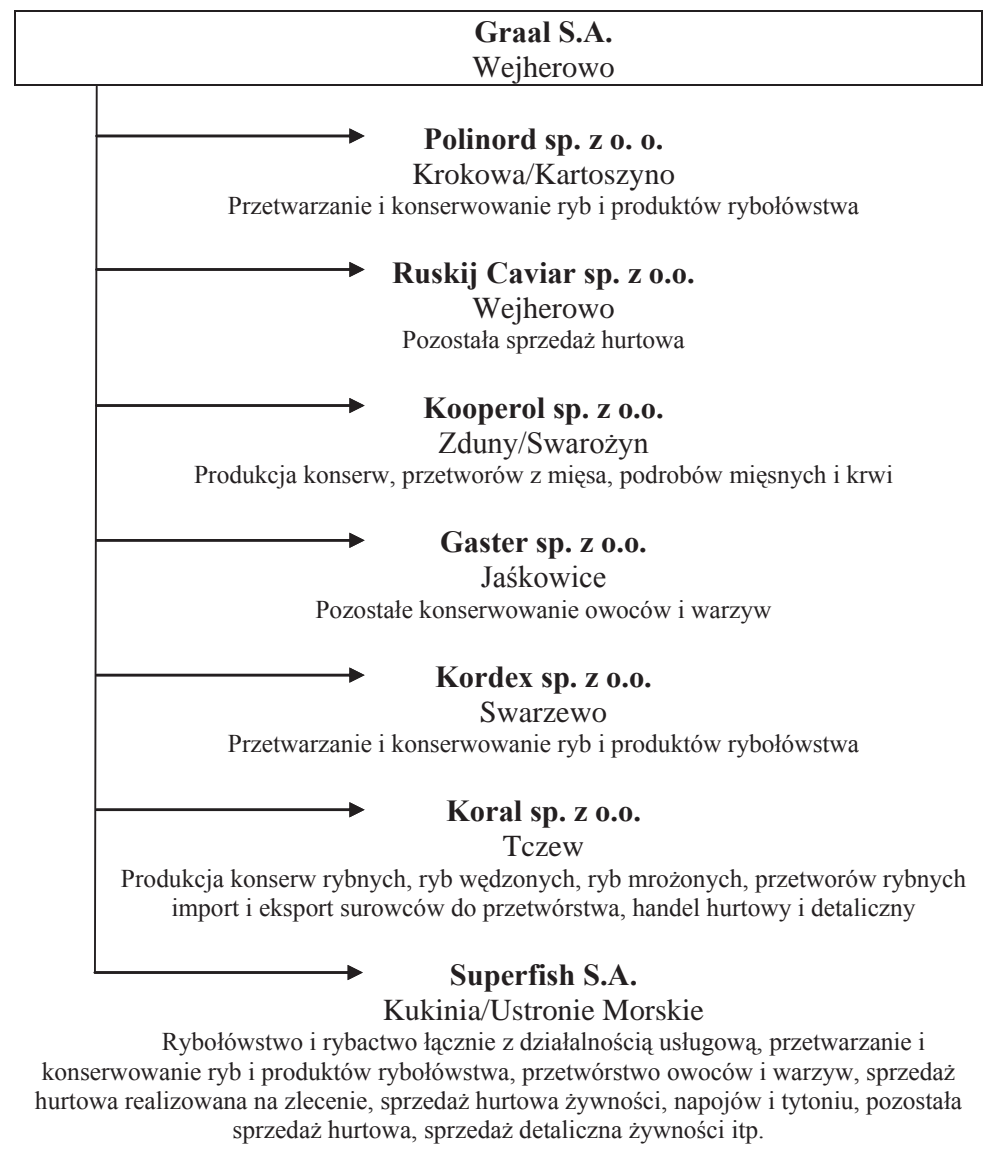

Ryc. 6. Struktura organizacyjna Grupy Kapitałowej Graal S.A., stan na 31.01. 2010

Źródło: Skonsolidowane sprawozdanie finansowe Grupy Kapitałowej Graal za okres 01.01.2009-31.12.2009, Wejherowo, kwiecień 2010 
Proces konsolidacji tej grupy, rozpoczęty w 2004 r., jest efektem konsekwentnej realizacji przyjętej strategii, która zakładała początkowo zbudowanie pozycji w tradycyjnym obszarze działalności, a następnie konsolidację rynku przetwórstwa ryb, której celem jest osiągnięcie pozycji dominującej w segmencie rynkowym. Konsolidacja polegająca na akwizycjach branżowych podmiotów o uzupełniających się profilach produkcji lub rejonach działania jest niezbędna także z punktu widzenia dalszych kroków w kierunku rozszerzenia działalności o nowe obszary rynkowe, np. pet food.

Jak wynika z opublikowanych raportów spółki ${ }^{6}$, istnieje wiele dodatkowych przyczyn realizowanej konsolidacji. Należą do nich:

- lepsze wykorzystanie kanałów sprzedaży,

- wdrożenie jednolitych metod zarządzania,

- większa siła negocjacyjna wobec dostawców i odbiorców,

- wspólna polityka marketingowa,

- efektywniejsze wykorzystanie zasobów produkcyjnych,

- ograniczenie sezonowości sprzedaży.

Innym obserwowanym rodzajem konsolidacji jest konsolidacja handlu rybami, którą reprezentuje utworzone w 2009 r., Polskie Centrum Dystrybucji Ryb. Ma ono poprawić dystrybucję ryb w Polsce w oparciu o sześć dużych firm dystrybucyjnych, głównie z południowej i wschodniej części kraju (ryc. 7).

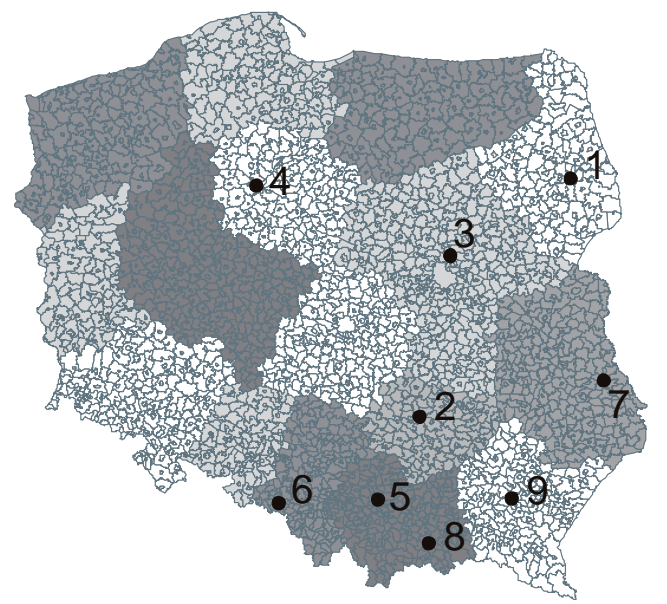

1-Akwen (Białystok)

2- Akwen II (Kielce)

3- Akwen III ( Radzymin)

4- K.M. Białas (Bydgoszcz)

5- Dar Morza (Kraków)

6- Neptun II (Wodzisław Śląski)

7- Transryb (Chełm)

8- Laps II (Nowy Sącz)

9- Laps (Rzeszów)

Ryc. 7. Struktura przestrzenna Polskiego Centrum Dystrybucji Ryb stan na 31.12.2009 r.

Źródło: opracowanie własne na podstawie: Bronikowski 2009

Należy zgodzić się z tezą, że istniejące kanały dystrybucyjne nie są sprawne, a co ważniejsze, nie gwarantują jednolitych jakościowo dostaw i to zarówno na poziomie regionalnym jak i krajowym (Kobielska 2009). Stąd podjęta przez PCDR konsolidacja handlu rybami, której celem według A. Bronikowskiego (2009) jest:

${ }^{6}$ Rozszerzony skonsolidowany raport kwartalny za I kwartał 2010 GK GRAAL oraz prezentacja GK GRAAL, przygotowana na konferencję prasową w dniu 14.02.2007 w Warszawie. 
- obsługa na jednolitych warunkach handlu detalicznego,

- poprawa systemów logistycznych,

- wspólne działania marketingowe,

- wspólne działania w zakresie handlu zagranicznego,

- wspólna pomoc w pozyskiwaniu środków unijnych.

Wreszcie trzeci typ konsolidacji zaobserwowanej na przykładzie funkcjonującej od 2004 r. spółki MORPOL S.A. z Duninowa k.Ustki to konsolidacja surowcowo-produkcyjna. Podejmowane przez przedsiębiorstwo działania mają na celu tworzenie łańcucha produkcyjnego, począwszy od hodowli ryb, poprzez przetwórstwo, aż do sieci handlu i dystrybucji. Aktywna polityka tworzenia własnej akwakultury poprzez przejmowanie istniejących farm i przetwórni łososi poza granicami kraju (Szkocja) ma zapewniać nie tylko stałe dostawy surowca, ale również łatwiejszy dostęp na rynki europejskie, a w szczególności trudny rynek francuski i brytyjski, z których skutecznie wypycha firmy norweskie (Barnowski 2010; Graniszewska 2010). Poza zapewnieniem sobie źródeł surowca spółka rozwija także sferę produkcyjną poprzez budowę nowych zakładów przetwórczych w kraju (w Słupskiej Specjalnej Strefie Ekonomicznej) i zagranicą (w Szkocji). W planach jest wejście $\mathrm{w}$ hodowlę ryb i uruchomienie produkcji w Niemczech i Francji. W sferze handlu i dystrybucji otwierane są kolejne przedstawicielstwa w Japonii, Wielkiej Brytanii, Francji, Niemczech i Stanach Zjednoczonych (Socha 2010).

Zaprezentowane przykłady procesów konsolidacji krajowego rynku przetwórstwa rybnego pozwalają na kilka wniosków.

- Po pierwsze, omawiane procesy rozpoczęte kilka lat temu pozwoliły na relatywnie dobre funkcjonowanie przedsiębiorstw, zwłaszcza w początkowym okresie ogólnoświatowego kryzysu gospodarczego.

- Po drugie, to dzięki dużej elastyczności dostaw, wysokiej jakości i precyzyjnej odpowiedzi na specyficzne potrzeby konsumenta, wynikającej z konsolidacji na poziomie surowca, przetwórstwa, handlu i dystrybucji udało się z powodzeniem wejść i zdobyć przewagę na wielu rynkach UE.

- Po trzecie, tylko duże podmioty gospodarcze są zdolne do konfrontacji z wielkimi hurtowymi sieciami handlowymi, które nie ugną się pod dyktatem silniejszego.

- Po czwarte, budowa nowoczesnych, ponadregionalnych kanałów dystrybucyjnych pozwala nie tylko na koordynację obsługi handlu detalicznego, ale również na wspólną politykę w handlu zagranicznym, marketingu, w pozyskiwaniu środków unijnych i wymianie doświadczeń, przez co osiągnięcie przewagi konkurencyjnej nad innymi pomiotami (krajowymi i zagranicznymi) jest zdecydowanie szybsze.

\section{Podsumowanie}

Reasumując, należy podkreślić, że zapoczątkowany w 2007 r. ogólnoświatowy kryzys gospodarczy zasadniczo nie zakłócił funkcjonowania krajowego przemysłu przetwórstwa rybnego. Jeżeli przyjmiemy, że właściwa ocena działalności możliwa jest na podstawie dłuższej perspektywy czasowej, to należy stwierdzić, że przetwórstwo rybne znajduje się nadal w trendzie wzrostowym, a obserwowane w latach 2008-2009 obniżenie wybranych wskaźników, w tym wielkości produkcji, należy uznać za sytuację przejściową. 
O wysokiej pozycji polskiego przetwórstwa rybnego zadecydowało wiele czynników. Niskie koszty pracy były tylko jednym z tych, które przyczyniły się do zdobycia rynków zagranicznych. Bardziej istotna była wysoka jakość produktów, która sprostała wymaganiom zagranicznych odbiorców. Było to jednak możliwe dzięki znacznym inwestycjom poniesionym w okresie przedakcesyjnym oraz w pierwszych latach członkostwa we Wspólnocie. Szczególnie ważne okazało się wsparcie z funduszy SAPARD i SPO „Rybołówstwo i przetwórstwo ryb 2004-2006". Dzięki tym środkom polskie zakłady przetwórstwa rybnego należą do najnowocześniejszych w Europie. Obecnie przetwórstwo rybne właściwie absorbuje środki unijne dzięki Programowi Operacyjnemu „Zrównoważony rozwój sektora rybołówstwa i nadbrzeżnych obszarów rybackich 2007-2013”. Największe dotychczasowe zaangażowanie środków pomocowych przypadało na dostosowanie floty rybackiej do nowych uwarunkowań rynkowych w ramach wspólnego, europejskiego rynku oraz na pobudzenie funkcjonowania akwakultury, rybactwa śródlądowego, przetwórstwa i obrotu produktami rybołówstwa i akwakultury.

Sukcesy polskich przedsiębiorstw były i są nadal możliwe dzięki konkurencyjnej cenie, możliwej do osiągnięcia dzięki konsolidacji rynku i wykorzystaniu efektów skali, ale także w wyniku zajęcia wysoce rentownej niszy, jaką jest obecnie przetwórstwo ryb łososiowatych. W tym przypadku istotna jest jednak wysoka jakość i precyzyjna odpowiedź na specyficzne potrzeby konsumenta.

Ważnym, a może najważniejszym w ocenie funkcjonowania przedsiębiorstw branży rybnej jest czynnik ludzki. Należy pamiętać, że poza silnymi i rozpoznawalnymi przedsiębiorstwami tworzącymi grupy kapitałowe do omawianej grupy należą zakłady małe, często rodzinne, o znaczeniu lokalnym. Niezależnie jednak od wielkości przedsiębiorstw w wielu widoczna jest otwartość na otoczenie, duża często intuicyjna chęć naśladownictwa liderów oraz wysoka aktywność w procesach konsolidacji rynku rybnego. Wymienione cechy dotyczą większości przedsiębiorców i to właśnie one pozwoliły na relatywnie szybką adaptację do zmieniającego się, turbulentnego otoczenia.

\section{Literatura}

Barnowski M., 2010, Wykupuje Szkocje, zainwestuje w Stupsku, „Głos Pomorza”, nr 231(1135).

Bronikowski A., 2009, Główni gracze na rynku ryb w Polsce, „AgroTrendy”, nr 24 (131).

Brzózka M., Stęniak Ł., 2010, Rok konsolidacji?, „Rynek Spożywczy”, nr 19.

Bykowski P.J., 2010, Przetwórstwo ryb w Polsce - szanse i zagrożenia, referat wygłoszony na XXXV Krajowej Konferencji - Szkolenia dla Hodowców Ryb Łososiowatych, Jastrzębia Góra, 6-8.10.2010.

Czapliński P., 1999, Gospodarka rybna województwa stupskiego na tle gospodarki morskiej Polski, Słupskie Prace Matematyczno-Przyrodnicze, nr 12 c, Wyd. Nauk. WSP, Słupsk.

Graniszewska M., 2010, Morpol kupuje farmy tososi, „Puls Biznesu”, nr 160.

Grygiel W., Horbowy J., Janusz M., Karnicki Z., Kołodziej K., Kołodziejski W., Kuzebski E., Pawlikowski B., Pieńkowska B., Rakowski M., Wyszyński M., 2009, Kompleksowa ocena segmentu pelagicznego polskiego rybołówstwa bałtyckiego celem wskazania możliwości podniesienia jego efektywności poprzez wdrażanie PO „Zrównoważony rozwój sektora rybołówstwa i nadbrzeżnych obszarów rybackich 2007-2013”, MIR, Gdynia.

Hryszko K., 2010, Handel zagraniczny rybami i owocami morza oraz ich przetworami, Rynek Ryb. Stan i perspektywy, nr 13, Wyd. IERiGŻ-PIB, Warszawa.

Kobielska Z., 2009, Ryba prosto z wody, „Fresh \& Cool Market”, nr 10. 
Kotler P., Caslione J., 2009, Chaotics: The Business of Managing and Marketing in The Age of Turbulence, Amacom, New York.

Koszarek M., 2005, Przetwórstwo ryb, [w:] Wstęna analiza trzech potencjalnych klastrów w województwie zachodniopomorskim, red. S. Szultka, Wyd. IBnGR, Gdańsk.

Kuzebski E., 2010, Połowy battyckie w 2009 r., „Wiadomości Rybackie”, nr 1-2 (173).

Lipszyc J.B., 2010, Kryzys trwat za krótko, „Rynek Spożywczy”, nr 16.

NOBE 2010, Quarterly forecasts of the economic development of Poland, Warszawa.

Orłowski W., Pasternak R., Flaht K., Szubert D., 2010, Procesy inwestycyjne i strategie przedsiebiorstw w czasach kryzysu, PARP, Warszawa.

Pawlikowski B., 2010, Możliwości i uwarunkowania wzrostu przetwórstwa szprotów bałtyckich na produkty żywnościowe w krajowym sektorze rybnym, „Wiadomości Rybackie”, nr 1-2 (173).

Rachwał T., 2006, Efekty restrukturyzacji wybranych przedsiębiorstw przemystowych Polski Poludniowo-Wschodniej, [w:] Efekty restrukturyzacji polskiej przestrzeni przemystowej, red. Z. Zioło, T. Rachwał, Prace Komisji Geografii Przemysłu PTG, nr 9, Wydawnictwo Naukowe AP, Warszawa-Kraków, s. 98-115.

Seremak-Bulge J., 2009, Dynamiczny rozwój i dobre perspektywy na przyszłość. I Edycja Rankingu Zakładów Rybnych, „Agro Trendy”, nr 24 (131).

Seremak-Bulge J., 2010, Rynek $i$ spożycie ryb w latach 2009-2010, referat wygłoszony na XXXV Krajowej Konferencji - Szkolenia dla Hodowców Ryb Łososiowatych, Jastrzębia Góra, 6-8.10.2010.

Socha R., 2010, Rekin na łososiu, „Polityka”, nr 16 (2752).

Szewczyk D., 2010, Ocena stanu sektora MŚP oraz najważniejsze instrumenty i kierunki wsparcia, PARP, Warszawa.

Szostak S., 2009, Wyniki gospodarki rybnej w 2008 r., „Wiadomości Rybackie”, nr 9-10 (171).

Szostak S., Rakowski M., Budny T., 2010, Morska gospodarka rybna w 2009 r. Wyd. MIR, Gdynia.

Zatrudnienie w sektorze rybołówstwa, Komisja Europejska, Urząd Oficjalnych Publikacji Wspólnot Europejskich, Luksemburg, 2006.

\section{Functioning of the fish processing industry in the period of economic crisis}

This article is an attempt to describe the functioning of the domestic fish processing industry under the conditions of the worldwide economic crisis. Research results show that, in spite of a distinct slowdown in the Polish economy, the fish processing sector is achieving very good financial results. This is mainly due to a high share of exports in sales, high technological innovation resulting from modernization of fish processing plants as well as from new organization and production solutions, and, in particular, from implementing consolidation strategy in the supply, production and market sphere.

\section{Dr Paweł Czapliński}

Akademia Pomorska, Słupsk

Instytut Geografii i Studiów Regionalnych

e-mail: somma@o2.pl 